\title{
PPP3CB Gene
}

National Cancer Institute

\section{Source}

National Cancer Institute. PPP3CB Gene. NCI Thesaurus. Code C38524.

This gene plays a role in calcium ion-dependent processes in the mitochondria and the regulation of signal transduction. 